\title{
PULMONARY O-METHYL TRANSFERASES
}

\author{
Francis C. P. LaW* John C. Drach and Joseph E. Sinsheimer \\ College of Pharmacy and Department of Oral Biology. School of Dentistry. The University of Michigan. \\ Ann Arbor, Mich. 48104. I. S.A.
}

(Received 26 May 1973: accepted 7 Juhe 1974)

\begin{abstract}
An investigation in vitro of pulmonary $O$-methyl transferases revealed the presence of microsomal phenol-O-methyl transferase and soluble and microsomal catechol-O-methyl transferases in guineapig lung tissue. Both phenol and catechol transferases also werc detected in rat and rabbit lung tissue Substrates of guinea-pig pulmonary phenol-O-methyl transferase included phenols. cresols and xylenols. but not alcohols and amines. Catechol-O-methyl transferases from both subcellular sources were found to have similar $\mathrm{pH}$ optima. magnesium ion requirements, $K_{m}$ values, and utilized norepinephrine. isoproterenol and dopamine as substrates, but not metaproterenol and salbutamol. These data for the pulmonary enzymes are similar to published values for liver $O$-methyl transferases.
\end{abstract}

It is recognized that the lung may have at least a secondary role similar to that of the liver in the detoxification or activation of exogenous compounds [1]. In support of this hypothesis are the common embryonic origin of lung and liver [2], and the efficient inactivation of many endogenous substances in a single passage through the lungs [3]. It is also significant in this regard that foreign compounds entering the body other than through the gastrointestinal tract would pass through the lungs before reaching the arterial circulation and the liver.

Nevertheless, relatively little has been reported concerning the biotransformations of exogenous materials by lung tissue. The presence of benzpyrene hydroxylase has been established in rat lungs [4-6] and more recently the mixed-function oxidases of liver and lung tissue have been compared [7-11]. The soluble fraction of rabbit lung homogenate in the presence of $S$ adenosyl- $\left[\right.$ methyl $\left.-{ }^{14} \mathrm{C}\right]$ methionine promotes the $\mathrm{N}$ methylation of a diverse series of amines $[12,13]$. However, studics of $O$-methyl transferases in lungs have been limited as part of more general studies of tissue and species distribution of the enzymes involved. For example. phenol- $O$-methyl transferase has been reported [14] to be present in guinea-pig with the lung tissue portion of the study being limited to phenol per se. In a similar study, catechol- $O$-methyl transferase has been detected in rat lung homogenates [15].

It is the purpose of this paper to further characterize O-methyl transferases in subcellular fractions prepared from guinea-pig lungs.

\footnotetext{
* Supported in part by Institutional Research Grant IN 40L from the American Cancer Society and a grant from the University of Michigan Cancer Research Institute. Abstracted from a dissertation submitted in partial fulfillment of the requirements for the Doctor of Philosophy degree. Present address: National Institute of Environmental Health Sciences, Research Triangle Park, N. C. 27709.
}

\section{Materials}

$S$-adenosyl-[methyl- $\left.{ }^{14} \mathrm{C}\right]$ methionine was purchased from New England Nuclear (Boston, Mass.) and International Chemical and Nuclear Corp. (Irvine. Calif.). Guinea-pigs (Hartley albino) of either sex weighing between 300 and $500 \mathrm{~g}$ were purchased from Camm Research Inc. (Wayne. N. J.). Salbutamol was a gift from Allen \& Hanburys Ltd. (Ware, England). Metaproterenol. $l$-isoproterenol and norepinephrine were obtained from Sigma Chemical Co. (St. Louis. Mo.). Dopamine. 3-methoxy-4-hydroxyphenethylamine and 4-methoxy-3-hydroxyphenethylamine were provided by Dr. Ara Paul. College of Pharmacy, University of Michigan (Ann Arbor, Mich.). The methoxy compounds were recrystallized from both methanol-ether and $n$-propanol ethyl acetate and are the compounds employed in a previous plant methylation study [16].

\section{Preparation of subcellular fractions}

Guinea-pigs weighing between 300 and $500 \mathrm{~g}$ were decapitated after being stunned by a blow on the head. The lungs were removed, rinsed, blotted, weighed and homogenized with 3 vol. of cold isotonic $\mathrm{KCl}$ in a Waring biendor at $0-4$. The preparation was centrifuged at $9000 \mathrm{~g}$ for $30 \mathrm{~min}$ at 0 to obtain the postmitochondrial supernatant fraction. Further centrifugation of the postmitochondrial supernatant at $105,000 \mathrm{~g}$ for $1 \mathrm{hr}$ at 0 gave soluble and microsomal fractions. Microsomal pellets were resuspended in $5 \mathrm{vol}$. of cold isotonic $\mathrm{KCl}$ and recentrifuged twice to remove soluble lung enzymes. Soluble fractions were dialyzed at 4 against $100 \mathrm{vol}$. of either isotonic $\mathrm{KCl}$ or $0.1 \mathrm{M}$ phosphate buffer, $\mathrm{pH} 7 \cdot 8$.

\section{Optimal incubation and extraction conditions}

The optimal amount of microsomes or supernatant equivalent to lung tissue per $0.5 \mathrm{ml}$ of incubation mix- 
ture for enzymatic reactions was determined as a scparate series of experiments and found to be: microsomal phenol- $O$-methyl transferase, $100 \mathrm{mg}$; microsomal catechol- $O$-methyl transferase, $100 \mathrm{mg}$; and soluble catechol- $O$-methyl transferase, $40 \mathrm{mg}$. The rates of these reactions were lincar with time for $30 \mathrm{~min}$. Furthermore, homogenates prepared either with a Waring blendor or a Potter-Elvehjem homogenizer in phosphate buffer or isotonic $\mathrm{KCl}$ did not change enzyme activitics in the subcellular fractions to a significant extent.

Toluene containing $1 \%$ isoamyl alcohol was used to extract the methyl ether derivatives of phenols from incubation mixtures. It was determined that in a single extraction this solvent removed approximately 80 per cent of these metabolites. Similarly, more than 80 per cent of $O$-methylated isoproterenol was removed by a single extraction with isoamyl alcohol. Furthermore, relatively little radioactivity $(<5$ per cent of the isoproterenol derivative) was extracted from blank incubations, indicating a preferential extraction of $O$-methylated isoproterenol as compared to methylated endogenous substrates. Isoamyl alcohol extracted the other methylated catechol derivatives equally well.

\section{Measurement of enzyme activity}

Microsomal phenol-O-methyl transferase. Microsomes equivalent to $100 \mathrm{mg}$ of lung tissue were added to a 15 $\mathrm{ml}$ glass-stoppered centrifuge tube containing $0.1 \mathrm{ml}$ of $0.5 \mathrm{M}$ phosphate buffer (pH 7.9). S-adenosyl-[methyl${ }^{14} \mathrm{C}$.methionine, (1 nmole) and substrate (2 $\mu$ moles) in a final volume of $0.5 \mathrm{ml}$. The reaction was stopped by the addition of $1 \mathrm{ml}$ of $0.5 \mathrm{M}$ borate buffer ( $\mathrm{pH}$ 9) after $30 \mathrm{~min}$ at $37^{\circ}$ and the mixture was extracted twice by $1^{\prime \prime}$ " isoamyl alcohol in toluene $(3 \mathrm{ml})$. The extracts were combined and a 2-ml aliquot was assayed for radioactivity. Values were corrected for a blank obtained by incubation of the reaction mixture without substrate and treated as above.

Soluble catechol-O-methyl transferase. Incubations were performed as above using soluble fraction equiv- alent to $40 \mathrm{mg}$ lung tissue in $\mathrm{pH} 7.8$ phosphate buffer with $0.5 \mathrm{mM} \mathrm{MgCl}$. After $30 \mathrm{~min}$ of incubation. $1 \mathrm{ml}$ of $05 \mathrm{M}$ borate buffer ( $\mathrm{pH}$ 11) was added to stop the reaction. Extraction was carried out with isoamyl alcohol $(10 \mathrm{ml})$ previously saturated with water. Aliquots $(4 \mathrm{ml})$ of the substrate and blank incubation cxtracts were counted for radioactivity.

Microsomal catechol-O-methyl transferase. Incubations were performed in plI 7.0 phosphate buffer with $2.5 \mathrm{mM} \mathrm{MgCl}_{2}$ and microsomes from $100 \mathrm{mg}$ lung tissue. All other conditions were the same as in the microsomal phenol-O-methyl transferase assay. Extraction was carried out with isoamyl alcohol $(10 \mathrm{ml})$.

\section{Metabalite identification}

Incubations of dopamine with microsomal and soluble enzymes were carried out along with the corresponding blanks. These incubations were terminated with $1 \mathrm{ml}$ of $0.5 \mathrm{M}$ borate buffer $(\mathrm{pH} 10)$ and extracted with ethyl acetate $(5$ and $10 \mathrm{ml}$ ). Extracts were combined and dried over $\mathrm{Na}_{2} \mathrm{SO}_{4}$. Aliquots $(1 \mathrm{ml}$ ) of the extracts were counted for radioactivity before the remainder was evaporated to dryness under a stream of nitrogen. The resilues were redissolved in elhanol $(50 \mu 1)$ before being applied on thin-layer chromatography plates. Authentic samples of 3,4-dimethoxyphenethylamine, 3-methox y-4-hydroxyphenethylamine and 4-methoxy-3-hydroxyphenethylamine were also applied on the chromatoplates. Chromatography was carried out in silica gel GF plates using two solvent systems: chloroform acetone-diethylamine (5:4:1) [16] and n-butanol-ammonium hydroxideethyl acetate $(3: 1: 1)$ [17]. The reference compounds were detected under ultraviolet light. Radioactivity measurement was carried out by placing $0.5-\mathrm{cm}$ strips in counting vials, adding $2 \mathrm{ml}$ methanol followed by $10 \mathrm{ml}$ scintillation solution, and counting in a liquid scintillation spectrometer.

\section{Determination of radioactivity}

Quantitative analysis of radioactivity was performed

Table 1. Species differences in lung transmethylation enzymes*

\begin{tabular}{|c|c|c|c|c|}
\hline Enzyme & Substrate & $\begin{array}{l}\text { Guinea-pigt } \\
\text { (Hartley) }\end{array}$ & $\begin{array}{c}\text { Rabbitt } \\
\text { (New Zealand white) }\end{array}$ & $\begin{array}{c}\text { Rat }{ }^{\dagger} \\
\text { (Sprague-Dawley) }\end{array}$ \\
\hline \multirow{3}{*}{$\begin{array}{l}N \text {-methyl } \\
\text { transferase } \\
\text { Phenol-O-methyl } \\
\text { transferase } \\
\text { Catechol-O-methyl } \\
\text { transferase }\end{array}$} & aniline & $<0.01$ & $0 \cdot 26(0 \cdot 20-0 \cdot 32)$ & $<0 \cdot 01$ \\
\hline & phenol & $2 \cdot 25(2 \cdot 24-2 \cdot 25)$ & $2 \cdot 11(2.02 \cdot 2 \cdot 20)$ & $2.27(2 \cdot 24 \cdot 2 \cdot 30)$ \\
\hline & l-isoproterenol & $8 \cdot 16(602-10 * 3)$ & $1.89(1.86-1.92)$ & $3.91(3.80-401)$ \\
\hline
\end{tabular}

* S-adenosyl- $\left[\right.$ methyl- $\left.{ }^{14} \mathrm{C}\right]$ methionine $(1 \mathrm{nmole})$, substrate $(2 \mu$ moles $), 0.1 \mathrm{ml}$ of $0.5 \mathrm{M}$ phosphate buffer (pH 7.9$)$ and postmitochondrial supernatant fractions equivalent to $100 \mathrm{mg}$ lung tissue in a final volume of $0.5 \mathrm{ml}$ were incubated for $30 \mathrm{~min}$ at $37 . N$-methyl transferase and catechol- $O$ methyl transferase incubations were extracted by isoamyl alcohol previously saturated with water. Phenol- $O$-methyl transferase incubations were extracted by $1 \%$ isoamyl alcohol in toluene.

$t$ Metabolite formation (nmoles/g tissue) was calculated from the difference between radioactivity extracted from incubations with substrate and the corresponding blank. The average of duplicate determinations is given with parentheses indicating ranges of results. 
by liquid scintillation spectrometry. Aliquots of extracts from incubation mixtures were added to counting vials containing $10 \mathrm{ml}$ of scintillation solutions made of $7 \mathrm{~g}$ 2,5-diphenyloxazole, $50 \mathrm{mg}$ 1,4bis(2,5-phenyloxazlyl)-benzene, $80 \mathrm{~g}$ naphthalene and $1000 \mathrm{ml} p$-dioxane. The vials were counted in a Bcckman LS-200 liquid scintillation system and cpm were converted to dis/min by the external standard ratio method.

\section{RESULTS}

\section{Species distribution of lung methyl transferase activity}

Methylating enzyme activities were examined with the postmitochondrial supernatant fractions of rat, rabbit and guinea-pig lungs using $S$-adenosyl-[methyl${ }^{14} \mathrm{C} 7$ methionine as the methyl donor (Table 1).

The data in Table 1 show that appreciable amounts of phenol- $O$-methyl transferase and catechol- $O$-methyl transferase were detected in lungs of guinea-pig. rat and rabbit. However, $N$-methyl transferase was detected only in rabbit lung preparations.

Pulmonary microsomal phenol-O-methyl transferase activity in guinea-pigs

Phenol- $O$-methyl transferase activity was detected mainly in the microsomes. Various hydroxyl and amino compounds were examined as possible substrates of microsomal phenol- $O$-methyl transferase of guinea-pig lungs. Cresols, xylenols, phenol, bromophenol and ethylphenol were found to be substrates for the enzyme (Table 2), while resorcinol and phlornglucinol were not methylated. No methylation was detected with aniline or tyramine as substrates or with alcohols (cyclohexanhexol, cyclohexanol, ethanol and glycerine).

The reaction rates of phenol at molar concentrations from $5 \times 10^{-2}$ to $5 \times 10^{-4}$ were determined in duplicate in the presence of phenol-O-methyl transferase by

Table 2. Substrate specificity of microsomal phenol- $O$ methyl transferase from guinea-pig lungs

\begin{tabular}{|c|c|}
\hline Substrate & $\begin{array}{c}O \text {-methylated substrates* } \\
\text { (nmoles/g tissue) }\end{array}$ \\
\hline$p$-Bromophenol & $1.40(1.39-1 \cdot 40)$ \\
\hline$p$-Cresol & $1.25(1.21-1.29)$ \\
\hline 3,4-Xylenol & $1.23(1 \cdot 15-1 \cdot 30)$ \\
\hline Phenol & $1.06(0.95-1.16)$ \\
\hline m-Cresol & $0.97(0.92-1.01)$ \\
\hline Ethylphenol & $0.91(0.85-0.97)$ \\
\hline 2,4-Xylenol & $0.75(0.70-0.80)$ \\
\hline 2,3-Xylenol & $0.70(0.65-0.75)$ \\
\hline 3,5-Xylenol & $0.63(0.52-0.73)$ \\
\hline$o$-Cresol & $0.59(0.49-0.68)$ \\
\hline 2,6-Xylenol & $0.38(0.36-0.39)$ \\
\hline 2,5-Xylenol & $0.33(0.29-0.36)$ \\
\hline
\end{tabular}

* Average of duplicate determinations; parentheses indicate ranges of results. the method of Lineweaver and Burk [18]. The $K_{m}$ value for phenol- $O$-methyl transferase with phenol as the substrate was $3.05 \times 10^{-2} \mathrm{M}$.

\section{Pulmonary catechol-O-methyl transferase activity}

Initial studies with guinca-pig lung homogenates indicated the presence of catechol- $O$-methyl transferase in both the microsomal and soluble fractions. The catechols-epinephrine, norepinephrine, isoproterenol, dopamine and catechol-were found to be substrates for the supernatant and microsomal fractions, whereas methylation was not detected for metaproterenol and salbutamol.

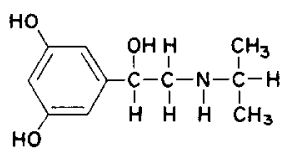

Metoproterenol

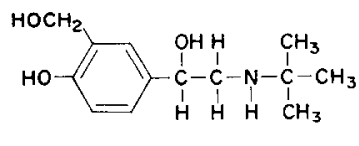

Solbutamol
While these preliminary studies had indicated the presence of enzyme activity in both the supernatant and microsomal fractions, it was possible that the reduced activity of the latter fraction was due to residual supernatant fraction adhering to the microsomes. To examine this possibility, microsomes were successively washed by resuspending in isotonic $\mathrm{KCl}$ and resedimenting at $105,000 \mathrm{~g}$. The enzyme activities of the supernalant and the microsomes were assayed each time after resuspension and sedimentation (Table 3 ).

Table 3. Subcellular catechol-O-methyl transferase activities of guinea-pig lung at various stages of washing and sedimentation

\begin{tabular}{ccc}
\hline & \multicolumn{2}{c}{$\begin{array}{c}\text { O-Methylated } d, l \text {-isoproterenol } \\
\text { formed* } \\
\text { (nmoles/g tissue) }\end{array}$} \\
$\begin{array}{c}\text { Times of } \\
\text { resuspension and } \\
\text { sedimentation }\end{array}$ & \multicolumn{1}{c}{ Supernatant } & Microsomes \\
\cline { 2 - 3 } & $29 \cdot 4(28 \cdot 8-29 \cdot 9)$ & $5 \cdot 0(4 \cdot 2-5 \cdot 7)$ \\
1 & $0 \cdot 5(0 \cdot 5-0 \cdot 5)$ & $2 \cdot 2(2 \cdot 0-2 \cdot 4)$ \\
2 & $<0 \cdot 1(0 \cdot 0-0 \cdot 1)$ & $2 \cdot 6(1 \cdot 5-3 \cdot 6)$ \\
3 & $<0 \cdot 1(0 \cdot 0-0 \cdot 1)$ & $2 \cdot 2(2 \cdot 0-2 \cdot 4)$ \\
4 & $0 \cdot 2(0 \cdot 1-0 \cdot 2)$ & $2 \cdot 4(2 \cdot 3-2 \cdot 5)$ \\
\hline
\end{tabular}

* Average of duplicate determinations: parentheses indicate ranges of results.

Microsomes washed and resedimented in this manner only once reach a constant level of activity. This activity was maintained over three additional washings with only minor activity appearing in the supernatant isotonic $\mathrm{KCl}$ washes.

In the present lung tissue study, a comparison was also made between the microsomal and soluble catechol- $O$-methyl transferases. $\mathrm{Mg}^{2+}$ concentrations, $\mathrm{pH}$ optimum values, $K_{m}$ values and substrate specificity were used as criteria in comparing the two enzyme preparations. 


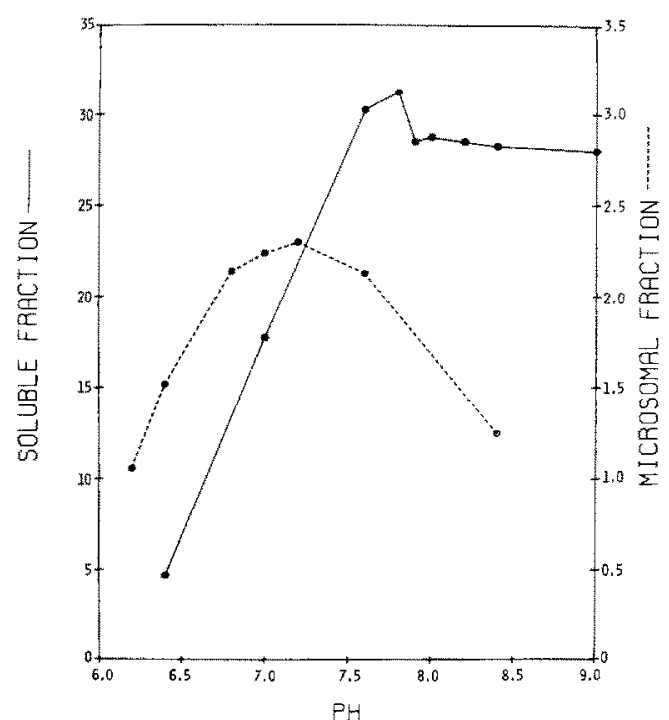

Fig. 1. Effect of $\mathrm{pH}$ on the $O$-methylation of isoproterenol by subcellular fractions of guinea-pig lung. Methylated product formed. nmoles/g of tissue, was determined as described for enzyme activity in lung tissue. Each point is the average of two determinations.

pH optimum. Pulmonary catechol-O-methyl transferases were incubated separately at various buffer $\mathrm{pH}$ values. The supernatant catechol-O-methyl transferase had optimal activity from $\mathrm{pH} 7.8$ to $9 \cdot 0$, whereas the microsomal catechol- $O$-methyl transferase had optimal activity from $\mathrm{pH} 6 \cdot 8$ to $7 \cdot 6$ (Fig. 1).

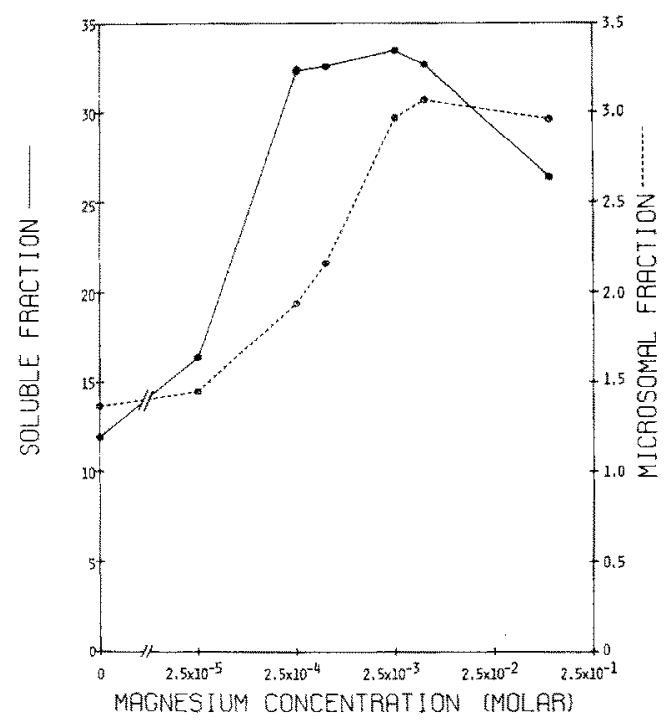

Fig. 2. Effect of magnesium concentration on the O-methylation of isoproterenol by subcellular fractions of guinea-pig lung. Methylated product formed, nmoles/g of tissue. was determined as described for enzyme activity in lung tissue.

Each point is the average of two determinations.
$\mathrm{MgCl}_{2}$ concentration. The effects of $\mathrm{Mg}^{2+}$ concentration on the pulmonary catechol-O-methyl transferases are summarized in Fig. 2. Maximal activity required $2.5 \times 10^{-4} \mathrm{M}$ and $2.5 \times 10^{-3} \mathrm{M} \mathrm{Mg}^{2+}$ for the soluble and the microsomal catechol-O-methyl transferases respectively. Note, however, that appreciable enzyme activity was detected in the absence of $\mathrm{Mg}^{2+}$. The effects of $\mathrm{Mg}^{2+}$ on lung enzymes were smaller than on the partially purified liver catechol-Omethyl transferase, as hepatic enzyme activity increased approximately 10 -fold in the presence of $\mathrm{Mg}^{2+}$ [15].

$K_{m}$ values. The reaction rates of the catechol-omethyl transferases using epinephrine as a substrate in molar concentrations from $3 \times 10^{-3}$ to $3 \times 10^{-5}$ were compared. Catechol- $O$-methyl transferases had $K_{m}$ values (calculated from these data) of $5.0 \times 10^{-4} \mathrm{M}$ and $1.13 \times 10^{-4} \mathrm{M}$ for the soluble and microsomal enzymes respectively.

Table 4. Substrate specificity of catechol-O-methyl transferase in guinea-pig lungs

\begin{tabular}{lc}
\hline \multicolumn{1}{c}{ Substrate } & $\begin{array}{c}\text { O-methylated substrates* } \\
\text { (nmoles/g tissue) }\end{array}$ \\
\hline $\begin{array}{l}\text { Soluble enzyme } \\
\text { d. } \text {-Norepinephrine }\end{array}$ & $11.38(11.37 \quad 11.38)$ \\
$\begin{array}{l}\text { l-Isoproterenol } \\
\text { Dopamine }\end{array}$ & $11 \cdot 11(10.9311 .29)$ \\
$\begin{array}{l}\text { Microsomal enzyme } \\
\text { l-Isoproterenol } \\
\text { d,-Norepinephrine } \\
\text { Dopamine }\end{array}$ & $10.23(9.95-10.50)$ \\
\hline
\end{tabular}

* Average of duplicate determinations: parentheses indicate ranges of results.

\section{Substrate specificity}

The extent of $O$-methylation using $l$-isoproterenol, norepinephrine and dopamine as substrates was compared in microsomal and soluble catechol-O-methyl transferases (Table 4). With $l$-isoproterenol, norepinephrine and dopamine as substrates, soluble enzymes were found to be 6-19 times more efficient than microsomes in the formation of $O$-mcthylated metabolites. $d, l$-Norepinephrine and $d, l$-isoproterenol were found to be the best substrates examined for $O$ methylation.

Chromatographic analyses of ethyl acetate extracts of microsomal and soluble subcellular fractions incubated with dopamine as a substrate indicated the formation of ${ }^{14} \mathrm{C}$-labeled 3-methoxy-4-hydroxyphenethylamine. However, it was necessary to increase substrate, S-adenosyl-[methyl- $\left.{ }^{14} \mathrm{C}\right]$ methionine and soluble enzyme concentrations 4-fold to demonstrate the presence of both $O$-methyl isomers by radiochromatography. The relative proportions of 3- and 4-methoxy metabolites were $2 \cdot 5$ and $2 \cdot 2$ for the soluble and microsomal catechol- $U$-methyl transferases respectively. 3,4- 
Dimethoxyphenethylamine was not detected in any radiochromatogram.

Comparison of liver and lung O-methyl transferase activity

The relative activities of lung and liver $O$-methyt transferase activities in the formation of $O$-methylated substrate per mg protein [19] per hr were compared in three guinea-pigs. The average \pm standard deviation for the three observations for the lung/liver activities were: microsomal phenol- $O$-methyl transferase, $28 \perp 26$; soluble catchol- $O$-methyl transferase, $0.4 \pm 0 \cdot 2$; microsomal catechol-O-methyl transferase, $1 \cdot 3 \pm 0.8$

\section{DISCUSSION}

The present investigation indicated that many mono-substituted phenols were substrates of guineapig lung phenol- $O$-methyl transferase, which was present mainly in the microsomal fraction. The results are consistent with the subcellular distribution and substrate specificity of guinea-pig liver phenol- $O$-methyl transferase reported previously by Axelrod and Daly [14]. The presence of phenol- $O$-methyl transferase in lungs of guinea-pig, rabbit and rat is also in agreement with the widespread occurrence of this enzyme in the liver of various species [14].

Our data also demonstrated that xylenols were substrates of pulmonary phenol- $O$-methyl transferase. Lunde et al. [20] have correlated the inhibitory effects of xylenols on vasoconstriction developed in isolated perfused lungs with the positions of the methyl groups on the aromatic ring. However, their inhibitory effects did not correspond to the extent of $O$-methylation which occurred in our phenol-O-methyl transferase incubations. The mechanisms by which xylenols exert their inhibitory effects on vaso-constriction developed in isolated perfused lungs remains to be elucidated; nevertheless, the present study does not support these xylenols as alternative substrates.

The presence of catechol- $O$-methyl transferase in guinea-pig lung is also consistent with the widespread species [15] and tissue [15.21] distribution of the enzyme. While Axelrod and Tomchick [15] have reported the presence of catechol-O-methyl transferase in post-mitochondrial supernatant fractions of rat lung homogenate, the present study extends this observation. Of considerable interest in this regard was the observation that catechol-O-methyl transferase is present in both soluble and microsomal subcellular fractions of guinea-pig lungs. Microsomal and particulate catechol- $O$-methyl transferase has been reported from other than lung tissue of rabbit and rat $[22,23]$. Thus, Alberici et al. [22] have found catachol-O-methyl transferase activity in both particulate material and soluble fraction of rat brain homogenate. Inscoe et al.

\footnotetext{
* F. C. P. Law, unpublished observation.
}

[23] have demonstrated the presence of microsomal catechol-O-methyl transferase in both rat and rabbit liver.

A comparison of the soluble and microsomal catechol-O-methyl transferases of guinea-pig lungs with regard to $\mathrm{pH}$ optimum, $\mathrm{Mg}^{2+}$ concentration requirement, $K_{m}$ values and substrate specificity showed that the catechol-O-methyl transferase of the two lung subcellular fractions is similar. These results are well within the wide range of $\mathrm{pH}[15,23-25], \mathrm{Mg}^{2+}$ $[15,25-27]$ and $K_{m}$ values $[25,28,29]$ previously reported for catechol- $O$-mcthyl transferases from other tissues.

Whereas metaproterenol, a resorcinol. was not a substrate for either soluble or microsomal catechol-Omethyl transferase of guinea-pig lungs, norepinephrine, isoproterenol and dopamine were found to be $O$ methylated by catechol-O-methyl transferases from both subcellular fractions. Similar observations have been reported by Briant $e t$ al. [30] in perfused dog lung in which isoproterenol and isothatine were extensively $O$-methylated but in which the resorcinol, terbutaline, was not metabolized.

Thin-layer chromatography results indicated the formation of ${ }^{14} \mathrm{C}$-labeled 3-methoxy-4-hydroxyphenethylamine in incubations using dopamine as substrate. Also, the presence of ${ }^{14} \mathrm{C}$-labeled 4 -methoxy-3hydroxyphenethylamine was demonstrated, but only when the substrate and cofactor concentrations in the incubation were increased 4-fold. Several investigators [31-33] have demonstrated the formation of a mixture of 3-and 4-O-methyl derivatives when dopamine was incubated with liver catechol- $O$-methyl transferase. In contrast, radioactive labeled norepinephrine has been found to be $O$-methylated mainly in the 3-position by the isolated perfused lungs of rat [34] and rabbit.*

Compared with the liver, guinea-pig lung contained more phenol- $O$-methyl transferase but less catechol- $O$ methyl transferase. These results are in agreement with previous published data reporting that soluble catechol-O-methyl transferase is found primarily in the liver [15], while phenol-O-methyl transferase is found mainly in the lung [14].

\section{REFERENCES}

1. D. V. Parke, in The Biochemistry of Foreign Compounds, p. 3. Pergamon Press, Oxford (1968).

2. B. I. Balinsky, An Introduction to Embryology, 3rd Edn, p. 524. Saunders, Philadelphia (1970).

3. J. R. Vane, in Importance of Fundamental Principles in Drug Evaluation (Eds. D. H. Tedeschi and R. E. Tedeschi), p. 217. Raven Press. New York (1968).

4. H. V. Gelboin and N. R. Blackburn. Cancer Res. 24, 356 (1964).

5. L. W. Wattenberg, M. A. Page and J. L. Leong, Cancer Res. 28,934 (1968).

6. L. W. Wattenberg, J. L. Leong and A. Galbraith. Proc. Soc. exp. Biol. Med. 127(2), 467 (1968).

7. G. E. R. Hook, J. R. Bend. D. Hoel, J. R. Fouts and T. E. Gram. J. Pharmac. exp. Ther. 182, 474 (1972). 
8. W. W. Oppelt, M. Zange, W. E. Ross and H. Remmer, Res. Conmun, Chem. Path. Pharmac. 1, 43 (1970).

9. H. Uehleke, Excerpta med. Int. Congr. Ser. No. 181, 94 (1968).

10. J. R. Bend, G. E. R. Hook, R. E. Easterling, T. E. Gram and J. R. Fouts, J. Pharmac. exp. Ther, 183, 206 (1972).

11. J. R. Bend, G. E. R. Hook and T. E. Gram, Drug Metab. Dispos. 1, 358 (1973).

12. J. Axelrod, J. Pharmac. exp. Ther, 138, 28 (1962).

13. J. V. Dingell and E. Sanders, Biochem. Pharmac. 15, 599 (1966).

14. J. Axelrod and J. Daly, Biochim. biophys. Acta. 159, 472 (1968).

15. J. Axelrod and R. Tomchick, J. biol Chem. 233, 702 (1958).

16. G. P. Basmadjian and A. G. Paul, Lloydia 34, 91 (1971).

17. C. R. Creveling, N. Morris, H. Shimizu, H. H. Ong and J. Daly, Molec. Phamac. 8, 398 (1972).

18. H. Lineweaver and I. D. Burk, J. Am. chem. Soc. 56, 658 (1934).

19. O. H. Lowry, N. J. Rosebrough, A. C. Farr and R. J. Randall, J. biol. Chem. 193, 265 (1951).

20. P. K. M. Lunde, B. A. Waaler and L. Walloe, Acta physiol. scand 72, 331 (1968).

21. I. Axelrod. W. Albers and C. D. Clement. J. Neurochem. 5, 68 (1959).
22. A. Alberici, G. Rodriguez de Lores Arnaiz and E. de Robertis, Life Sci, 4, 1951 (1965).

23. J. K. Inscoe, J. Daly and J Axelrod, Biochem. Pharmac 14, $1257(1965)$.

24. M. Assicot and B. Bohuon, Eur. J. Biochem. 12, 490 (1970).

25. B. Nikodijevic, J. Daly and C. R. Creveling, Biochem. Pharmac, 18, 1577 (1969)

26. B. Belleau and J, Burba, J. med. Chem. 6, 755 (1963).

27. S. Senoh, Y. Tokuyama and B. Witkop, J. Am. chem. Soc. 84, 1719 (1962).

28. J. Axelrod and E. S. Vesell, Molec. Pharmac. 6, 78 (1970).

29. R. Knuppen, W. Lubrich, O. Haupt, U. Ammerlahn and H. Breuer, Hoppe-Sayler's Z, physiol. Chem. 350, 1067 (1969).

30. R. H. Briant, E. W. Blockwell, F. M. Williams, D. S. Davies and C. T. Dollery, Xenoblotica 3, 787 (1973).

31. J. W. Daly. J. Axelrod and B. Witkop, J. biol. Chem. 235 , $1155(1960)$.

32. F. A. Keuhl, Jr., M. Hichens, R. E. Ormond, M. A. P. Meisinger, P. H. Gale, V. J. Circillo and N. G. Brink. Nature, Lond. 203, 154 (1964).

33. C. R. Creveling, N. Dalgard, H. Shimizu and J. W. Daly, Molec. Pharmac. 6, 691 (1970).

34. J. Hughes, C. N. Gillis and F. E. Bloom, J. Pharmac. exp. Ther. 169, 237 (1969). 